ISSN: 0213-2079 - ISSN electrónico: 2386-3889

DOI: http://dx.doi.org/10.14201/shhmo2015377191

ZEMSKY SOBORS OF THE LATE $16^{\text {th }}-$ EARLY $17^{\text {th }}$ CENTURY IN RUSSIA: HISTORIOGRAPHICAL STEREOTYPES IN THE REFLECTION OF HISTORICAL SOURCES

\title{
Los Zemskie Sobory en la Rusia de finales del siglo XVI y comienzos del XVII: los estereotipos historiográficos reflejados en las fuentes históricas
}

\section{Dmitry Vladímirovich LISÉYTSEV}

Instituto de Historia de Rusia de la Academia de Ciencias de Rusia, Moscú Correo-e: liseitsev@mail.ru

RESUMEN: En los estudios dedicados a la historia de los Zemskie Sobory rusos se estableció la tradición de trazar un parangón entre los Sobory y las asambleas representativas de los países europeos de los siglos XVI y XVII (el Parlamento en Inglaterra, los Estados Generales en Francia, las Cortes en España). Se considera que a finales del siglo XVI y comienzos del XVII (especialmente durante el Período de los Tumultos) tuvo lugar el auge de los Zemskie Sobory, coincidiendo con la debilidad del gobierno central, que, actuando en condiciones de guerra civil, buscaba el apoyo de la sociedad en las instituciones estamentales representativas. Entretanto, el análisis de las fuentes históricas primarias no permite afirmar que los Zemskie Sobory tuvieran en este período mucha más inportancia que con anterioridad. Los Zemskie Sobory, incluyendo las mayormente estudiadas asambleas electivas de 1598 y 1613, fueron organizados con violaciones serias del procedimiento electivo, y las provincias no fueron representadas tal como, sin embargo, era descrito en la documentación oficial. El problema de la importancia de los Zemskie Sobory en el sistema político del Estado Moscovita a comienzos del siglo XVII requiere futuras investigaciones.

Palabras clave: Zemsky Sobor; representación estamental; Período de los Tumultos; Boris Godunov; Mikhail Romanov. 
DMITRY VLADÍMIROVICH LISÉYTSEV

ZEMSKY SOBORS OF THE LATE 16TH - EARLY 17TH CENTURY IN RUSSIA:

HISTORIOGRAPHICAL STEREOTYPES IN THE REFLECTION OF HISTORICAL SOURCES

ABSTRACT: In the works on the history of the Russian Zemsky Sobors, there is a tradition to draw a parallel between the Sobors and representative bodies of European countries in the $16^{\text {th }}-17^{\text {th }}$ centuries (the English Parliament, the French States General, the Spanish Cortes). It is believed that the end of the $16^{\text {th }}$ - early $17^{\text {th }}$ century, especially the Time of Troubles, was the heyday of Zemsky Sobors (when a weak Central government, in the conditions of the civil war, had to look for support in the organs of estate representation). Meanwhile, the analysis of historical sources does not allow to assume that during this period the Zemsky Sobors played a greater role than they did previously. Even the most studied Zemsky Sobors - the elective Sobors of 1598 and 1613 - were held with serious violations of election procedures, and the provinces were not represented to the extent it was described in the official documents. The question of the place of the Zemsky Sobors in the political system of Muscovite state at the beginning of the $17^{\text {th }}$ century requires further analysis.

Key words: Zemsky Sobor; Estate Representation; The Time of Troubles; Boris Godunov; Mikhail Romanov.

\section{INTRODUCTION}

In Russian historiography the question of Zemsky Sobors of the $16^{\text {th }}-17^{\text {th }}$ centuries has been one of the discussed problems since the middle of the $19^{\text {th }}$ century. Representatives of various scientific schools interpret differently their origins, function, and place in the political system of Muscovy. This phenomenon was given diametrically opposite assessments. Some experts deny Sobors the ability to play an independent role in conditions of a strengthening samoderzhavie (autocracy) in Russia. Others perceive in them the first sprouts of civil society and elected authorities in Russia. Even a century ago S. A. Avaliani, who studied the existing literature on the history of the Zemsky Sobors, noted a high degree of politicization of works on the subject: «the Zemsky Sobors were a favorite topic for the publications that always counted on a certain socio-political effect, in accordance with the time of their appearance» ${ }^{1}$.

It is difficult to disagree with this statement. Representatives of the Slavophil trend in historical scholarship highly praised the value of the Zemsky Sobors, associating their appearance with the development of the old Russian Veche traditions and representing, therefore, Sobors as an organic and unique phenomenon,

1. Avaliani, S. A.: Zemskie sobory. Literaturnaya istoria zemskikh soborov. Odessa, 1916, p. 3 . 
DMITRY VLADÍMIROVICH LISÉYTSEV

ZEMSKY SOBORS OF THE LATE 16TH - EARLY 17TH CENTURY IN RUSSIA:

HISTORIOGRAPHICAL STEREOTYPES IN THE REFLECTION OF HISTORICAL SOURCES

inherent only to the political development of Russia. The Westernizer trend in the historiography, by contrast, pursued the idea of parallels between the Russian Zemsky Sobors and representative bodies of Western Europe (the English Parliament, the French States General, the Spanish Cortes, the German Landtag). However, the apparent inconsistency between the Russian Sobors and their alleged European counterparts has led the representatives of this trend to pessimistic conclusions: Zemsky Sobors were «wrong», «flawed» political bodies.

The tradition to compare the Zemsky Sobors with the European representative bodies was continued in the works of Soviet historians. For example, a major scholar of Russian history of the $16^{\text {th }}-17^{\text {th }}$ centuries, M. N. Tikhomirov, in the article on the Zemsky Sobors, printed in 1958, expressed regret that «our scholars dismiss the subject, repeating outdated century- and half-century-old judgments». Having criticized the study of the Zemsky Sobors by V. O. Klyuchevsky and accused him of bias, Tikhomirov commended the work of V. N. Latkin, released in 1885, wherein the Russian Zemsky Sobors were compared with the Western representative bodies ${ }^{2}$. From this point on, in the Russian historical science a tradition have been formed to draw an analogy between the Zemsky Sobors and coincident with them political institutions of Western Europe. So that the Russians «estate-representative bodies» would not look as an insipid and weak copy of the European counterparts in such a comparison, it was important to find as many as possible references to the convocations of Zemsky Sobors in Russia. Consequently, since the 1960s a real «hunting for the Sobors» has begun, when any mention of the term «Sobor» in the documents was interpreted as evidence of convening a "previously unknown to scholars Zemsky Sobor» ${ }^{3}$. The view of the Zemsky Sobors as an estate-representative body of power was finally established in the Russian historiography by the monograph of L. V. Tcherepnin, a first-rate specialist in the history of the $17^{\text {th }}$-century Russia, wherein he summarized the accumulated information about this political institution ${ }^{4}$.

In this essay, we are going to analyze the information on the Zemsky Sobors of the late $16^{\text {th }}-$ early $17^{\text {th }}$ century, starting with the Sobor of 1598 , when Boris Godunov was proclaimed a tsar, and ending with the Sobors of the beginning

2. Tiкномirov, M. N.: «Soslovno-predstavitelnye uchrezhdeniya (Zemskie sobory) v Rossii XVI veka», Tikнomirov, M. N.: Rossiyskoe gosudarstvo XV-XVII vekov. Moscow, 1973, p. 69; LATKIN, V. N.: Zemskie sobory Drevney Rusi, ikh istoria i organizatsiya sravnitelno s zapadnoevropeyskimi predstavitelnymi uchrezhdeniyami. Saint Petersburg, 1885; KLYuchevsky, V. O.: «Sostav predstavitelstva na Zemskikh soborakh Drevney Rusi (posvyashchaetsya B. N. Chicherinu)», KLuchevsky, V. O.: Sochineniya $v$ devjati tomakh, t. VIII. Moscow, 1990, pp. 227-334.

3. KoreTsky, V. I.: «Zemsky sobor 1575 g. i chastichnoe vozrozhdenie oprichniny», Voprosy istorii, vol. 5, 1967, pp. 32-50.

4. TCherepnIN, L. V.: Zemskie sobory Russkogo gosudarstva v XVI-XVII vv. Moscow, 1978. 
DMITRY VLADÍMIROVICH LISÉYTSEV

ZEMSKY SOBORS OF THE LATE 16TH - EARLY 17TH CENTURY IN RUSSIA:

HISTORIOGRAPHICAL STEREOTYPES IN THE REFLECTION OF HISTORICAL SOURCES

of the reign of Michael Fyodorovich, i.e. during the period, considered in the historical literature as the heyday of the Sobors' practice ${ }^{5}$.

\section{The electoral Zemsky Sobor of i 598}

Despite numerous attempts of scholars to find evidence of a regular operation of estate-representative bodies in the $16^{\text {th }}$-century Russia, materials have been collected only about two Zemsky Sobors, whose convocation is not disputed by researchers. These are the Sobors of 1566 and $1598^{6}$. Meanwhile, even the history of such a political event (so popular among researchers of Russian history at the turn of the $17^{\text {th }}$ century) as the Zemsky Sobor of 1598, when Boris Godunov was elected a tsar, still has many controversial issues. One of them is a persistent silence on the Sobors of the documents chronologically close to the election of Boris Godunov to the throne.

As is well known, the election of Tsar Boris Fyodorovich at the Sobor is dated to 21 February, 1598. But the first document officially informing the population about the accession of a new monarch refers to $15 \mathrm{March}$, 1598. It is a letter sent to Kostroma by Patriarch Job. The procedure of the elections is described there as follows: after the death of Tsar Fyodor Ivanovich, the last member of the Moscow branch of the Rurik dynasty, his widow, Tsarina Irina Fyodorovna, rejected a petition of the clergy and the boyars to take power over the country ${ }^{7}$. The request to the Tsarina Dowager was made by representatives of the higher clergy, but not all of them, as there were only those people that happened to be in Moscow at the time of Tsar Fyodor's death. Tsarina Irina was approached not only by the clergy, but also by boyars and the whole «Zarsky cycle» (Boyarskaya Duma). Other petitioners were under a general title of «national multitude of people of the Russian state». The same ranks later asked Irina Fyodorovna to crown her brother, Boris Godunov, and asked Boris Godunov himself to accept the sceptre ${ }^{8}$.

5. LeOnTJEv, A. K.: «Gosudarstvenny stroy», Ocherki russkoy kultury XVII veka, t. 1. Moscow, 1979, pp. 301-302.

6. KoRZInIN, A. L.: «Zemsky sobor 1566 g. v otechestvennoy istoriografii», Vestnik SPbGU, seria 2, n. 3, 2011, pp. 11-23.

7. M. N. Tikhomirov even wrote that Tsarina Irina was elected to the throne by the Zemsky Sobor. However, the only argument in favor of this rather controversial thesis is wording of Piskarevsky letopisets, composed no earlier than 1645. According to it, "vsya Russkaya zemlya» swore allegiance to the Tsarina, and she accepted the power, as Piskarevsky letopisets puts it, at the request of «all ranks and all Orthodox Christians» (Tiкномirov, M. N.: «Soslovno-predstavitelnye uchrezhdeniya», p. 65).

8. Akty, sobrannye v bibliotekakh I arkhivakh Rossiyskoy imperii Arkheograficheskoy ekspeditsiey imperatorskoy Akademii nauk (hereafter AAE), vol. II. Saint Petersburg, 1836, pp. 1-2. 
DMITRY VLADÍMIROVICH LISÉYTSEV

ZEMSKY SOBORS OF THE LATE 16TH - EARLY 17TH CENTURY IN RUSSIA:

HISTORIOGRAPHICAL STEREOTYPES IN THE REFLECTION OF HISTORICAL SOURCES

Approximately the same picture is presented by the speech of Boris Godunov, delivered by him during the coronation on 3 September, 1598: a new autocrat claimed that he was accepting the sceptre by election and at request of the higher clergy, the boyars «and all Orthodox Christians». In a tsar's charter to the town of Sol' Vychegodskaya, dated on 14 September 1598, there is a more detailed list of ranks that asked Boris Godunov to accept the crown, but it also does not emphasize the fact that he was elected by a Zemsky Sobor. According to the charter, he came to the throne because of «pleasure, benevolence, and will» of God, «intercession» of Our Lady, «prayers» of saints, a «blessing» of his sister, Tsarina Irina, «request and supplication» of the clergy, and «petitions» of the people of other ranks. There is no mention of a Zemsky Sobor in a text of oath, dated on 15 September, 1598. According to this document, Godunov took power with his sister's blessing, and she in turn listened to «the supplication and crying» of «national multitude of people»?

In the «Approved Charter» (Utverzhdionnaya gramota) of Boris Godunov, which was apparently drawn up in the spring of $1599^{10}$, there is another version of the monarch's election. The story is supplemented with important details that were to noticeably strengthen the concept of legitimate authority of Boris Fyodorovich. Among these details, there is the first indication that a Zemsky Sobor took place in Moscow, which, if this document is to be trusted, was attended by representatives of the higher clergy and secular delegated from provincial towns Having been refused by both the Tsarina Dowager and her brother, the Patriarch decided to wait for the fortieth day after the death of Fyodor Ivanovich. During this period, representatives of the higher clergy were to come to Moscow, those «who are used to attend the great Sobors». In addition, it was necessary to await the arrival of the «serving people of Muscovy and all sorts of people», with regard to whose sending to Moscow the Patriarch had sent out letters ${ }^{11}$. At the end of mourning for deceased Tsar Fyodor, the Patriarch ordered to all intending to come to Moscow «to be for a Sobor at his (place)». The Patriarch spoke on behalf of all ranks «that were in Moscow», declared that it was their unanimous desire to see Boris Godunov enthroned. In return, those who «came from distant towns» stated their unanimous consent to this candidate ${ }^{12}$.

9. AAE, vol. II, pp. 54, 56, 58 .

10. Liseytsev, D. V.: «K datirovke sostavleniya tsarskikh utverzhdennykh gramot kontsa Xvi - nachala XVII v.», Mininskie chteniya: Trudy uchastnikov mezhdunarodnoy nauchnoy konferentsii. Nizhegorodsky gosudarstvenny universitet imeni N.I. Lobachevskogo (24 - 25 oktyabrya 2008 g.). Nizhny Novgorod, 2010, pp. 24-31.

11. It is strange that not one of them has survived. Moreover, these charters with orders to send elected people to Moscow are only mentioned by implication in 'The Approved Charter'.

12. AAE, vol. II, pp. 24-25. 
DMITRY VLADÍMIROVICH LISÉYTSEV

ZEMSKY SOBORS OF THE LATE 16TH - EARLY 17TH CENTURY IN RUSSIA:

HISTORIOGRAPHICAL STEREOTYPES IN THE REFLECTION OF HISTORICAL SOURCES

It is noticeable that during the year that had passed since the election of Boris Godunov to the throne, the ideological elaboration of the official version of the accession of a new monarch had been considerably improved. In addition to the previous arguments of kinship between Boris Godunov and the royal family and the unanimous desire of all ranks to see him on the throne, an appeal to the authority of a Zemsky Sobor attended by provincial delegates had appeared.

As it can be seen, in more than a year since the election to the throne of Boris Godunov, the ideological elaboration of the official version of the accession of the new monarch was greatly improved. In addition to the previous arguments of kinship between Boris Godunov and the Royal family, and the unanimous desire of all ranks to see him on the throne, in «The Approved Charter» appears the appeal to authority of the Zemsky Sobor, which was attended provincials.

It is worth noting that in the documents drawn up during the first year after the Boris Godunov's election to the throne there is not a word about the election of a new tsar at a Sobor, or about convocation of that Sobor, (except for stereotyped phrases about praying of «national multitude of people»). There was no time for the organization of a Zemsky Sobor, though: to see this, it is enough to recall the chronology of events of the winter of 1598. Tsar Fyodor died on 6th January, Tsarina Irina took the veil nine days later, on 15 January. Only after this there theoretically could be talk about election of a monarch. The Zemsky Sobor, if The Approved Charter is to be trusted, was assembled at the Patriarch's courtyard as early as on 17 February, and on 21 February a tsar was elected. Even if strongly desired, in those conditions it was impossible to gather representatives of the provinces in the capital so quickly. To alert the outlying towns to the necessity to send representatives to Moscow, it would take at least two or three weeks. Accordingly, during the month, from a taking the veil by Tsarina Irina Fyodorovna to the beginning of Sobor's meetings, there was no way the representatives of «distant towns», mentioned by The Approved Charter, could have arrived in the capital. Moreover, there is reason to believe that provincial towns, even lying not too far from Moscow, learnt about Tsar Fyodor Ivanovich's death after much delay. In Ryazan' district, for example, at least till 20 January, 1598 charters for estates continued to be sent on behalf of Tsar Fyodor, who died two weeks earlier ${ }^{13}$.

Indications are that only those being in Moscow at the time took part in the election of Tsar Boris. However, in the documents simultaneous to the Godunov`s enthronement there is not a word about the election: the candidacy of Boris Godunov looks uncontested. French mercenary Captain Jacques Margeret who

13. Akty sluzhilykh zemlevladeltsev XV - nachala XVII v. Sbornik dokumentov, vol. II. Moscow, 2001, p. 204. 
DMITRY VLADÍMIROVICH LISÉYTSEV

ZEMSKY SOBORS OF THE LATE 16TH - EARLY 17TH CENTURY IN RUSSIA:

HISTORIOGRAPHICAL STEREOTYPES IN THE REFLECTION OF HISTORICAL SOURCES

served in Russia since 1600 , mentions in his book that after the death of Tsar Fyodor Boris Godunov himself encouraged the organization of a Zemsky Sobor for the election of a monarch: «he wanted to convene the States of the country [les Estats du pays] properly, namely eight to ten people from each town, so that the whole country would unanimously decide whom should be elected». The Frenchman added, though: «it took time», and therefore the Boris Godunov`s ascension to the throne took place without the participation of the $«$ States» ${ }^{14}$. The analysis of documents, thus, allows us to question the previously undoubted fact of the convocation of a Zemsky Sobor of 1598 in the form as it is presented in the later Approved Charter, i.e. with participation of elected representatives from the provinces.

3. The idea of an approval of tsar's power at a Sobor in Russia in the EARLY I $7^{\text {TH }}$ CENTURY

Even if the accession of Boris Godunov to the throne happened without convocation of a Zemsky Sobor, the official propaganda, as we have seen, since as early as the spring of 1599 , was trying to instill an idea in the people that the election of a new monarch had occurred with the consent and the unanimous election of the Zemsky Sobor. This means that this very procedure of approval of the monarch on the throne was perceived as correct or, at least, desirable in the Russian society of the time.

In the context of a growing political crisis in Muscovy, this fact gave rise to the corresponding political phraseology: factions involved in the struggle for power were forced to appeal to the authority of Zemsky Sobors. After Boris Godunov's death, there was the same rhetoric in use while attempting to transfer the power to his son, Prince Fyodor Borisovich, as at his father's enthronement. In the charter to Sol' Vychegodskaya, sent on 29 April, 1605, it was reported that after the death of Tsar Boris the clergy, the boyars, the merchants and the «national multitude of the people of Russian state» asked his widow and son to take the crown ${ }^{15}$. Obviously, in the circumstances of the beginning of the Time of Troubles, the Godunovs' government had no time or opportunity to convoke a Zemsky Sobor, which, however, did not prevent their supporters from adducing the authority of cite on the authority of the «national multitude of the people of Russian state».

Similar attempts of political groups to confer legitimacy upon their actions were not always convincing to their contemporaries, doubting, for example, that

14. Marzheret J. Sostoyanie Rossiyskoy imperii. J. Marzheret v dokumentakh i issledovaniyakh: (Teksty, kommentarii, stat'i). Moscow, 2007, p. 126.

15. AAE, vol. II, p. 87. 
in 1606 Tsar Vasily Shuysky was elected to the throne by a Zemsky Sobor. This monarch quickly earned a reputation as a «samovenechnik», having taken the throne not by election, but by usurpation. However, supporters of Shuysky tried to give an appearance of a national approval to his reign. The official wording of royal charters sent to Perm' and Putivl' in May of 1606, shortly after the accession of Vasily Shuysky, can mislead and impress the wrong conclusion about the fact of a national election (at a Sobor) of this monarch, who, if the text of the charters is to be trusted, was approached by «all sorts of people of Muscovy State» ${ }^{16}$ with an offer of the crown.

Having never succeeded in the effort to deceive their contemporaries, the authors of political manifestos of the early $17^{\text {th }}$ century were able to mislead the scholars, studying that period, especially as while looking for evidence of active practice of the Sobors in Russia, they were glad to be mistaken. As a result, in the historical works concerning the issue of Zemsky Sobors, one can find references to the following Sobors:

- 1604 (convoked in connection with the news of a possible incursion of the Crimean Tatars into the Russian territory);

- 1605 (the trial of the conspirators Princes Shuyskys);

- 1606 (the election to the throne of Tsar Vasily Shuysky);

- 1607 (two Sobors - one for the cancellation of the oath to pseudo-Dmitry I, the other - for the trial of Impostor pseudo-Petr);

- 1610 (the deposition of Vasily Shuysky and the transfer of power to the boyar government);

- 1611 (Sobor under the First Militia Force);

- 1612 (Sobor under the Second Militia Force) ${ }^{17}$.

To the list of hypothetical Sobors of the beginning of the $17^{\text {th }}$ century, another one can be added, that has not been mentioned before by researchers. «Belsky chronicler» (Belsky letopisets) argues that the decision on sending ambassadors to negotiate with the Swedes in 1608 was made «on the advice of the whole of Muscovy State» ${ }^{18}$.

16. AAE, vol. II, p. 101; Akty vremeni pravleniya Vasiliya Shuyskogo. (19 maya 1606 - 17 inlya 1610 g.). Moscow, 1914, p. $1,3$.

17. Koretsky, V. I.: «Materialy po istorii Zemskogo sobora 1575 goda i postavlenii Simeona Bekbulatovicha "velikim knyazem vsea Rusii"”, Arkheografichesky ezhegodnik za 1969 god. Moscow, 1971, p. 298; TCHEREPNIN, L. V.: Zemskie sobory, pp. 148-186.

18. Polnoe sobranie russkikh letopisey, vol. 34. Moscow, 1978, p. 249. 
DMITRY VLADÍMIROVICH LISÉYTSEV

ZEMSKY SOBORS OF THE LATE 16TH - EARLY 17TH CENTURY IN RUSSIA:

HISTORIOGRAPHICAL STEREOTYPES IN THE REFLECTION OF HISTORICAL SOURCES

Speculations on the functioning of these Sobors are usually based on highly shaky ground. In some cases, they rely on rather late sources, for example, razryadnye knigi («books of orders») designed in the late 1630s (in the case of the Sobor of 1604), or on even later compiled «Piskarevsky chronicler» (Piskarevsky letopisets) in relation to the Sobor that denounced pseudo-Petr in 1607. The «Belsky chronicler»'s reference (not synchronous to the described events) to sending ambassadors to negotiate with the Swedes in 1608 is of a similar kind. In other cases, the existence of a Sobor is proved by not quite clear references of foreign authors, describing Russian actuality with the help of West European terms. This can be exemplified by Margeret's information about the condemnation of Princes Shuyskys in 1605 «in the presence of persons elected by all estates» («en présence de personnes choisies de tous estats» $)^{19}$. Statements about the functioning of a Sobor are occasionally based on the desire to see something more in political procedures organized by the government than they were in reality. For example, in February of 1607 the merchant and artisan people of Moscow were ordered to come to the Assumption Cathedral, where a charter of the former Patriarch $\mathrm{Job}^{20}$ was read out to them. This event also lays a claim to be a Zemsky Sobor.

At the same time, it should be noted that the recurring need of the supreme power to appeal to the (even fictitious) authority of Zemsky Sobor attests that the idea of the necessity of convocation of Sobors to address the critical issues of national importance in the context of a beginning civil war in Muscovy and the fall of the authority of the central government was forming more and more distinctly in the Russian political thought.

On 20 July, 1610, three days after the overthrow of Tsar Vasily Shuysky, a charter was sent to Perm, reporting about the coup happened in the capital. The charter also reproduced the text of the oath, temporarily handing over the power in the country to the boyar government, «council of seven boyars». The text of the oath indicated in no uncertain terms that the election of a new tsar should be carried out with the participation of elected representatives of towns and provinces: «to choose the sovereign of Muscovy with us, with all sorts of people, the whole land, and having consulted with towns, whom God will give to Muscovy state». But the declaration of this intent had not yet acquired a distinct form at the time, as there was no summons to send delegates to Moscow for the election of the tsar in the charter sent to Perm'. Four days later, on 24 July, 1610 , in Moscow there was composed a charter directed to the Siberian town of Surgut. Its contents almost duplicate the charter to Perm' of 20 July. But there is an important addition in it - an order to send delegates to the capital: «And

19. Marzheret J. Sostoyanie Rossiyskoy imperii, pp. 94, 167.

20. AAE, vol. II, pp. 156-157. 
you would ... send to Moscow (people) of all ranks, one from the each» ${ }^{21}$. The charter does not specify to which purpose the delegates should come to the capital, although the objective is clear from the context of the document, «to choose the sovereign of the whole land, having gathered with all the towns»22. A similar in content charter was sent to Kazan on $29 \mathrm{July}$, 1610. It contained an order to send delegates to Moscow, «and of all sorts of people, and of the Tartars, and of the Chuvash, and of the Cheremis (Mari) and of the Votyaks (Udmurts) to send to Moscow as many people as one should ${ }^{23}$.

Before long Moscow, however, swore to Polish Prince Wladyslaw, not have waited for the Zemsky Sobor. A corresponding agreement with Hetman Stanisław Źókiewski, the leader of the Polish army that had approached the Russian capital, was signed on 17 August, 1610, a month after the overthrow of Vasily Shuysky ${ }^{24}$. Two days later, on 19 August, 1610 a charter was sent from Moscow to Perm', informing its residents about what had happened. In the charter it was stated that the inhabitants of Perm' were invited to participate in the election of the tsar («and you, people of all ranks, are told to go to Moscow to elect the sovereign of Muscovy»), despite the fact that in the above-cited charter of 20 July there was no order to send people to Moscow for the elections. This, however, did not prevent the Muscovite government from blaming the provinces for the disruption of the electoral Zemsky Sobor, "And from the towns no people have yet come»; therefore, the decision to take the oath to the Polish prince was made without the participation of the delegates of towns, «and we, the whole Muscovite state... kissed the cross (swore) to Prince Wladyslaw» ${ }^{25}$.

The idea of engaging representatives of the whole state to make the most important political decisions was developed not only in the capital, but also in the camp of the enemies of the Moscow government, supporters of pseudoDmitry II. In the agreement made in February of 1610 between the recent associates of the impostor and Polish King Sigismund III about the election of Prince Wladyslaw to the Russian throne it was stipulated that reforms in the judicial system were to be approved by «the whole land»; as were all issues not listed in the agreement $\mathrm{t}^{26}$.

21. Sobranie gosudarstvennykh gramot $i$ dogovorov, khranyaschikbsya v Gosudarstvennoy kollegii inostrannykh del (hereafter SGGiD), vol. II. Moscow, 1819, pp. 388-390.

22. SGGiD, vol. II, pp. 388-389.

23. AAE, vol. II, pp. 281-282.

24. SGGiD, vol. II, p. 391.

25. AAE, vol. II, p. 279.

26. Akty, otnosyaschiesya $k$ istorii Zapadnoy Rossii, sobrannye $i$ izdannye Arkheograficheskoy ekspeditsiey imperatorskoy Akademii nauk, vol. IV. Saint Petersburg, 1851, p. 314-317. 
DMITRY VLADÍMIROVICH LISÉYTSEV

ZEMSKY SOBORS OF THE LATE 16TH - EARLY 17TH CENTURY IN RUSSIA:

HISTORIOGRAPHICAL STEREOTYPES IN THE REFLECTION OF HISTORICAL SOURCES

\section{The Zemsky Sobor of i6i 3 and the election of Michael Romanov to THE THRONE}

Prince Wladyslaw had never legally become the Russian tsar, as the final agreement between the government of the «council of seven boyars» and the Polish king about that had not been signed, and Wladyslaw himself had not arrived in Moscow for the coronation. The latter fact, however, did not stop the Poles from occupying Moscow Kremlin by their garrison and from issuing charters on behalf of «Tsar Wladyslaw Zhigmontovich». Before long the candidature of the Polish prince to the Russian throne lost the support of most Russians. At the beginning of 1611 the First Militia Force was created for the liberation of Moscow and after his actual disintegration at the end of the same year the Second Militia Force started to be mustered in Nizhny Novgorod under the leadership of Prince Dmitry Pozharsky and Kuz'ma Minin. On 26 October, 1612 Moscow was cleared of the invaders, and immediately afterwards the question about choosing of a new tsar was raised. As early as on the 15 November, 1612 a charter was sent from the liberated capital to Veliky Novgorod that once again proclaimed the already formulated principle: the tsar should be elected with the indispensable participation of the provinces. The leaders of the victorious Militia Force wrote about it to Nizhny Novgorod, Kazan, Astrakhan, Siberia, towns of Severyans ${ }^{27}$.

The meeting of the electoral Zemsky Sobor was supposed to start on 6 December, 1612. This date appears in the charters sent to the Sol' Vychegodskaya, Ostashkov, and Beloozero. The governors of these towns were ordered to send to Moscow by the deadline 10 delegates of the town clergy, the townspeople, and the peasants. However, it was impossible to gather people in Moscow in time, as, for example, it took more than two weeks for the charter to reach Beloozero, and it was received only on 4 December, when it was out of the question to have time to send the delegates in time ${ }^{28}$. Having realized the disruption of the time-frame of the convocation in Moscow in mid-December, 1612, it was decided to delay the beginning of the working of the Sobor for a month, so the delegates were to be sent by 6 January, 1613. But this date, as it turned out, was also unrealistic. A charter with this request was sent to Arkhangelsk only on 31 December; therefore, the residents of Arkhangelsk could have sent their representatives to Moscow only

27. Dopolneniya k Aktam istoricheskim, sobrannye i izdannye Arkheograficheskoy komissiey, vol. I. Saint Petersburg, 1846, pp. 291-292, 294.

28. Podvig Nizhegorodskogo opolcheniya, vol. 2, Nizhny Novgorod, 2011, p. 316;Zamyatin, G. A.: «Iz istorii borby Shvetsii i Polshi za moskovsky prestol v nachale xvII veka. Padenie kandidatury Karla Filippa i votsarenie Mikhaila Fedorovicha», ZAMYATIN, G. A.: Rossiya i Shvetsiya v nachale XVII veka. Ocherki politicheskoy i voennoy istorii. Saint Petersburg, 2008; Novye akty Smutnogo vremeni. Akty podmoskovnykh opolcheniy i Zemskogo sobora 1611-1613 gg., Chteniya v Imperatorskom obshchestve istorii i drevnostey rossiyskikh pri Moskovskom universitete, vol. 4, 1911, pp. 99-100. 107. 
DMITRY VLADÍMIROVICH LISÉYTSEV

ZEMSKY SOBORS OF THE LATE 16TH - EARLY 17TH CENTURY IN RUSSIA:

HISTORIOGRAPHICAL STEREOTYPES IN THE REFLECTION OF HISTORICAL SOURCES

with a two-month delay. The same can be said about the population of Siberia and the outlying towns - Astrakhan and Pskov.

And arrival of delegates from Smolensk and Veliky Novgorod was certainly out of the question, as the first of these towns was under the Polish occupation, and the second - under the Swedish occupation. However, the residents of towns located not too far from Moscow also did not hurry up to get to the capital. For example, representatives of Kazan, Nizhny Novgorod, and Kaluga (the last town is located only $180 \mathrm{~km}$ away from Moscow) had failed to arrive in the capital in the time for the tsar's elections. The charter to Kazan with a request to send their representatives to Moscow as soon as possible was sent on 25 January, 1613, well past the new deadline for the convocation of a Zemsky Sobor ${ }^{29}$. This «political inertia» of the Russians was caused by the circumstances of the time: it was difficult to decide to travel several hundreds of versts (versta $=1066,8 \mathrm{~m}$ ) by winter roads across the country engulfed by civil war.

The structure of the Zemsky Sobor is usually reconstructed on the basis of «The Approved Charter» of Tsar Michael Fyodorovich. According to this document, legally conferring rights of the new tsar, the election of the monarch was attended by the residents of 43 towns and districts, situated no more than $400-500$ miles from Moscow (at the time it took about 10 days to cover). The dating of this document's drafting to 1613 raises serious doubts: many facts testify that the collection of signatures on the «Approved Charter» had continued until the end of $1616^{30}$. The sources synchronous to the session of the Zemsky Sobor registered the presence of representatives from 25 provincial towns in the capital, Belgorod, Borovsk, Bryansk, Vladimir, Vologda, Kadom, Kalyazin, Kashira, Kolomna, Kursk, Mtsensk, Murom, Novosil, Odoev, Oskol, Pogoreloe Gorodische, Rostov, Ryazan, Suzdal, Torzhok, Toropets, Tula, Ustyuzhna Zhelezopolskaya, Chern, and Yaroslavl.

The representation of the Zemsky Sobor convoked at the beginning of 1613 in Moscow was obviously far from full, but, nevertheless, it started to work. The above-mentioned towns were represented by people of different social status - among them there were members of the clergy, the provincial nobility, the merchants, the urban Cossacks, and the peasants. The higher clergy and the Moscow court ranks were well represented at the Sobor. But, it is interesting, that among the participants of the Zemsky Sobor of the end of 1612 - the beginning of

29. Zimin, A. A.: «Akty Zemskogo sobora 1612-1613 gg.», Zapiski otdela rukopisey Gosudarstvennoy ordena Lenina biblioteki SSSR i meni V.I. Lenina, vol. 19. Moscow, 1957, p. 187-188; KoreTsKy, V. I., LuKichev, M. P., STANISLAvsKY, A. L.: «Dokumenty o natsionalno-osvoboditelnoy borbe v Rossii v 1612-1613 gg.», Lukichev, M. P.: Boyarskie knigi XVII veka: Trudy po istorii i istochnikovedeniyu. Moscow, 2004, pp. 214-215.

30. LiseYTSEv, D. V.: «K datirovke», pp. 24-31. 
DMITRY VLADÍMIROVICH LISÉYTSEV

ZEMSKY SOBORS OF THE LATE 16TH - EARLY 17TH CENTURY IN RUSSIA:

HISTORIOGRAPHICAL STEREOTYPES IN THE REFLECTION OF HISTORICAL SOURCES

1613 the free Cossacks were completely unnoticeable, although its number greatly expanded during the Time of Troubles due to the inflow of fugitive peasants and slaves, townspeople, strelets, and even impoverished landowners ${ }^{31}$. Charters issued by the Zemsky Sobor in January, 1613, meticulously list representatives of almost all social strata of the Russian society, with the exception of the Cossacks and atamans ${ }^{32}$. This persistent ignoring of the Cossacks in the official documents made in the name of the Zemsky Sobor suggests that the Cossacks and their atamans were not initially included in the number of participants of the tsar's election.

It may be assumed that it was caused by the fact that the Cossacks of the time were declassed and did not fit into the traditional structure of the Russian society, having no binding to any estate, or a territorial entity. This is also evidenced by the «Tale about the Zemsky Sobor of 1613», the source, originating precisely from the Cossack environment. The anonymous author of «The Tale» wrote that Moscow boyars and princes were engaged in the election of the tsar, and the Cossacks had not been consulted, waiting for the boyars' decision for a long time. Not having awaited the boyars' decision, the Cossacks started to discuss the candidates for the tsar's crown ${ }^{33}$.

Contrary to the official version that was later established, the winning candidacy of Tsar Michael Romanov was not the only and unanimously approved at the Zemsky Sobor. There were initially considered options of an invitation to the Russian throne of a Polish or a Swedish prince (the latter one was especially supported by the boyars). There were supporters of a two-year-old son of pseudoDmitry II and Marina Mniszech - «Vorionok». Sources also mention the names of nine representatives of noble boyar families who aspired to the throne (among them were the military leaders of the Militia Force - Princes D.T. Trubetskoy and D. M. Pozharsky, who actually hold all the power in Moscow in their hands at the time $)^{34}$.

The election of the tsar was hindered by the abundance of candidates, as well as by a too much protracted arrival of the towns' delegates at the capital. Being in Moscow and the time and having a numerical superiority over the nobility, but

31. Narodnoe dvizhenie v Rossii v epokhu Smuty nachala XVII veka, 1601 - 1608 gg.: Sbornik dokumentov. Moscow, 2003, pp. 207-208; SuкHотіN, L. M.: Pervye mesyatsy tsarstvovaniya Mikhaila Fedorovicha. (Stolptsy Pechatnogo prikaza). Moscow, 1915, p. 66, 96, 97, 101, 116, 173, 188; Zimin, A. A.: «Akty Zemskogo sobora 1612-1613 gg.», p. 187-188; Zabelin, I. E.:Minin i Pozharsky. 'Pryamye' i 'krivye' v Smutnoe vremya. Saint Petersburg, 2005, p. 232.

32. Zabelin, I. E.: Minin i Pozharsky, p. 228; Koretsky, V. I., Lukichev, M. P., Stanislavsky, A.L.: «Dokumenty o natsionalno-osvoboditelnoy borbe v Rossii v 1612-1613 gg.», pp. 214-215.

33. Morozov, B. N. y Stanislavsky, A. L. (eds.): «Povest' o Zemskom sobore 1613 goda», Voprosy istorii, n. 5, 1985, pp. 90-94.

34. LiseYTSEv, D. V.: «Demokratia Smutnogo vremeni: kak prokhodil Zemsky sobor 1613 goda», Rodina, n. ${ }^{\circ}$ 2, 2013, pp. 14-17. 
DMITRY VLADÍMIROVICH LISÉYTSEV

ZEMSKY SOBORS OF THE LATE 16TH - EARLY 17TH CENTURY IN RUSSIA:

HISTORIOGRAPHICAL STEREOTYPES IN THE REFLECTION OF HISTORICAL SOURCES

not being among the participants of the Zemsky Sobor, the Cossacks did not add stability to the situation. According to one of the evidences, they were originally completely against the idea of a convocation of a Sobor and offered to resolve the issue much quicker by casting lots among three candidates (another source originating from the Cossack environment ascribes to the idea of a lot to the boyars, though). At that, both sources point to the Cossacks' support of the candidacy of Michael Romanov, although in the first place they offered the candidacy of the head of the current government - Prince Dmitry Trubetskoy, who was trying to bribe the Cossacks by daily feasts. However, the candidacy of Trubetskoy had not found support in the boyar environment. The participants of the Sobor also rejected other candidates proposed by the Cossacks, including Michael Romanov.

A discord among the delegates of the Sobor had led to the fact that some participants began to leave the capital. Some of the Cossacks, dissatisfied with the delay in settling of the question of the tsar's crown, went to Ataman Zarutsky, who tried to enthrone the son of Marina Mniszech. As a result, the outcome of the struggle for the throne was settled by a force intervention of the Cossacks, who demanded Michael Romanov to be crowned on the basis of his kinship with the extinguished tsar's dynasty. According to Russian captives who were in Novgorod (occupied by Swedes) in the summer of 1614, «the Cossacks and common people came running with a great noise and broke into the Kremlin to the boyars and the Duma members, scolding them violently», demanding to immediately give them a tsar. Not listening to the boyars' objections, they insisted on swearing to Michael at once ${ }^{35}$.

Michael Romanov was proclaimed a tsar on 21 February, 1613 under pressure of the Cossacks. The Zemsky Sobor, that they tried to convene with the maximum participation of representatives of provincial towns and districts had not had enough time to gather in full. In fact, there was a military coup in Moscow that day, and the Cossacks were the main driving force behind it. A change in the distribution of political forces was reflected by the inclusion of atamans and the Cossacks in the official list of ranks, on whose behalf since 25 February, 1613 charters were sent from Moscow to the towns (a month earlier the Cossacks were not mentioned in the charters of the Zemsky Sobor $)^{36}$. That was actually the end of the Zemsky Sobor of 1613 before it properly began.

35. Sbornik Novgorodskogo obshchestva lubiteley drevnosti, vol. V. Novgorod, 1911, p. 30; Povest' o Zemskom sobore 1613 goda, pp. 93-94; Zamyatin, G. A.: «Iz istorii borby Shvetsii i Polshi za moskovsky prestol», pp. 141, 236.

36. SGGiD, vol. III, Moscow, 1822, p. 11; Koretsky, V. I., Lukichev, M. P., Stanislavsky, A. L.: «Dokumenty o natsionalno-osvoboditelnoy borbe v Rossii v 1612-1613 gg.», pp. 214, 221. 
DMITRY VLADÍMIROVICH LISÉYTSEV

ZEMSKY SOBORS OF THE LATE 16TH - EARLY 17TH CENTURY IN RUSSIA:

HISTORIOGRAPHICAL STEREOTYPES IN THE REFLECTION OF HISTORICAL SOURCES

\section{The Zemsky Sobors of the first Years of the reign of Michael Fyodorovich}

In historiography it is an established belief that the first years of the reign of Michael Romanov (1613-1619) became the heyday of Zemsky Sobor. According to experts, during the mentioned years the Sobor was working, without dissolution for consecutive three years. This strange fact is usually explained by the fact that at first, not having become firmly established in its power, the government of Michael Romanov needed a wide support of different social strata. The idea of a continuous work of the Zemsky Sobor in 1613 - 1619 was established in the Russian historical science in the late $19^{\text {th }}$ century. And after the repetition of this idea in a classic work of L. V. Tcherepnin, it became almost an axiom ${ }^{37}$.

Meanwhile, the information about Zemsky Sobors of the first years of the reign of Michael Romanov is extremely scarce and leaves more possibilities for the construction of hypotheses, rather than well-founded scientific findings. There is not much evidence of the Sobor's activities during those years. In most cases, researchers of the political history of Russia prove the work of Sobors by tsar's charters, wherein there are appeals to the Sobor about acceptance and approval of a decision (most often such appeals are in the form of lists of the ranks relevant to the political action). However, such statements of the central government about themselves do not prove the fact that a Sobor was actually active.

In particular, it is believed that there is surviving evidence about the activity of the Zemsky Sobor in 1614, relating to the March, April and September. In March of 1614, as it is stated in a number of studies, the Sobor sent charters to the Cossacks of Zarutsky; in April in the name of the Sobor a new emergency tax - «fifth money» - was introduced; and in September the Sobor made a decision about a counteraction against the rebel troops of the Cossacks, operating to the north of Moscow. But at the same time in the charters directed in March of 1614 to the Volga Cossacks, as well as in April charters about introduction of an additional tax, there is only a list of the ranks, on which behalf the central authority was acting. In these documents, a Zemsky Sobor is not even mentioned, and conclusions about its functioning are based solely on the inclusion of phrase 'all ranks of people' in the text of the tsar's charters ${ }^{38}$.

37. Platonov, S. F.: «Moskovskie Zemskie sobory xvi i xvi vekov», Platonov, S. F.: Sobranie sochineniy v shesti tomakh, vol. 1. Moscow, 2010, p. 101; Platonov, S. F.: «Zametki po istorii moskovskikh Zemskikh soborov», Platonov, S. F.: Sobranie sochineniy v shesti tomakh, vol. 3. Moscow, 2012, p. 17; TCherepnin, L. V.: Zemskie sobory,p. 216; LeONTJEv, A. K.: «Gosudarstvenny stroy», pp. 301-302.

38. AAE, vol. III, San Peterburgo, 1836, p. 54-61, 65-70; Veselovsky, S.B.: Sem'sborov zaprosnykh I pyatinnykh deneg v pervye gody tsarstvovaniya Mikhaila Fedorovicha. Moscow, 1908, pp. 96-99. 
DMITRY VLADÍMIROVICH LISÉYTSEV

ZEMSKY SOBORS OF THE LATE 16TH - EARLY 17TH CENTURY IN RUSSIA:

HISTORIOGRAPHICAL STEREOTYPES IN THE REFLECTION OF HISTORICAL SOURCES

There is one more appeal to the authority of a Zemsky Sobor, dated to June of 1614 (recently discovered by us). In an effort to stop the mass exodus of landowners from the Russian troops, the tsar, with boyars, the higher clergy, and 'all ranks of people' decided to confiscate the estate of deserters. This meeting was called a Sobor in the charter sent from the Razriadny prikaz (Department of Service) to the Pomestny prikaz (Department of lands) ${ }^{39}$. A sobor is also mentioned in the documents, dated September of 1614. In «Dvortsovy Razryad» there is a record that on 1 September «at the Sobor» Tsar Michael Fyodorovich talked to the higher clergy, the members of the Boyarskaya Duma and 'all ranks with all sorts of people'. A Sobor is referred in the text of nakaz (instructions), handed over, on 4 September, 1614, to the deputation sent to negotiate with rebellious Cossacks in the northern districts: «And at the Sobor... all ranks of people had decided $»^{40}$. But in this case again, there is no dead certainty that in 1614 a Zemsky Sobor was really functioning in Moscow; and a reference to its authority might have been only a formulation, that had been included in the tsar's charter to give it extra weight.

The composition of the «Sobor» of 1614 remains unclear, whether the elected people were engaged in its meetings or the power, as it so often happened up to then and afterwards, was content with gathering only of the higher clergy, members of the Boyarskaya Duma, and representatives of other ranks and provincial towns, being in Moscow at that time. And, accordingly, it is still an unanswered question, whether the Sobor really functioned without interruptions during the early years of the reign of Michael Romanov or the central government, from time to time, assembled an «enlarged meeting of the government» in difficult cases, engaging persons of different ranks, whose representation occurred at random.

For the first years of the reign of Michael Romanov there is documented information about the convening of a Zemsky Sobor, by special invitation of delegates to Moscow, only for the beginning of 1616.There are extent charters, sent to towns in January of 1616, with an order to send people for the participate in a Zemsky Sobor. In particular, on 12 January, 1616, it was written to Perm to remind about sending of three elected representatives of the townspeople to Moscow; similar orders were sent to Sol' Vychegodskaya and Tot'ma (the latter town was ordered to send also a person from the peasants). In this case, we definitely know that the

39. LiseyTSEv, D. V.: «Novoe izvestie o deyatelnosti sobora v 1614 godu», Soslovnoe predstavitelstvo $v$ Rossii v kontekste evropejskoy istorii (vtoraya polovina XVI-seredina XVII vv.). Mezhdunarodnaya nauchnaya konferentsiya. 7 - 10 oktyabrya 2013 g. Tezisy dokladov. Moscow, 2013, pp. 72-74.

40. Dvortsovye razryady, izdannye vtorym Otdeleniem sobstvennoy ego imperatorskogo velichestva kantselyarii (hereafter DR), vol. I, Saint Petersburg, 1850, pp. 143-144; SGGiD, vol. III, pp. 100, 101. 
Sobor was held in late February - mid-March of 1616. It was assembled to get an approval for the introduction of a new extraordinary tax - the so-called «Third fifths» (Tretya piatina - it was the most severe one for the country's population, and brought an additional sum of up to 190 thousand Rubles to the budget). We also know that the Zemsky Sobor were attended by representatives («elected people») from at least 28 towns, among whom were residents of rather distant towns - Arkhangelsk, Perm', Alatyr ${ }^{341}$. By the way, in this case we are able to estimate the time it took the delegates from the provinces to gather in the capital: charters about sending representatives to Moscow started to be send, probably, already at the end of 1615, and the meeting of the Zemsky Sobor was held not earlier than at the end of February. Consequently, it was required at least two two and a half months to organize a Sobor.

However, the Zemsky Sobor of 1616 is the only one, on which convening there is not a shadow of doubt. References in the literature to the Zemsky Sobor of September of 1616 as well as of $1617-1618$, look unconvincing. For example, the assumption that the collection of the fourth «fifths» (new extraordinary tax) in the summer of 1617 was sanctioned by the decision of a Zemsky Sobor is based solely on the supposition (and an arguable one, at that) that all previous «fifths» were collected exclusively with consent of a Sobor. The fact of work of some Sobors raises doubts because of their almost instantaneous convocation (whereas, as it was shown, it required a lot of time). For example, on 11 September, 1616 the government of Tsar Michael Romanov decided to discuss the peace terms with Sweden «at a Sobor». The very next day, the «Sobor» was held. Another such case took place two years later. Having received the news about the resumption of the Polish attack on Moscow on 8 September, 1618, as early as the next day Tsar Michael was expounding this problem at the Sobor ${ }^{42}$. It would be naive to believe that it was possible to succeed in assembling a true Zemsky Sobor in so short space of time. The attempts to explain this promptness by the fact that a Sobor could have worked continuously for several years in a row, are lame, as we have neither tsar's charters with the orders to send delegated to these Sobors, nor acts of these Sobors, nor petitions of their participants.

The available evidence does not allow to state that during the Time of Troubles the Zemsky Sobor was convoked more often than usually or worked without interruption for a long time. The political weight of the Sobors also had not changed, as before, they continued to confirm decisions of the tsarist govern-

41. AAE, vol. III, pp. 111; Veselovsky, S. B.: Sem' sborov zaprosnykh i pyatinnykh deneg, pp. 164-165; Tcherepnin, L. V.: Zemskie sobory, p. 220-224; VosковоYNiкоvA, N. P.: «K istorii finansovoy politiki russkogo gosudarstva v nachale xvII v.», Istoriya SSSR, n. ${ }^{\circ} 3,1986$.

42. TCherepnin, L. V.: Zemskie sobory, pp. 224, 227-228; DR, vol. I, pp. 354-355. 
DMITRY VLADÍMIROVICH LISÉYTSEV

ZEMSKY SOBORS OF THE LATE 16TH - EARLY 17TH CENTURY IN RUSSIA:

HISTORIOGRAPHICAL STEREOTYPES IN THE REFLECTION OF HISTORICAL SOURCES

ment, remaining an obedient political instrument in the hands of the government, not limiting but strengthening the autocratic power by giving its decisions the appearance of sobor's ones.

This does not mean that the government was not interested in the opinions of subjects. In this regard, the following episode is revealing. On 27 June, 1617 English diplomat James Merrick asked Tsar Michael for permission for English merchants to transport free of duty their goods through Russian land to Persia. In response to the envoy, the tsar said that such issues cannot be resolved «without the advice of the whole state» ${ }^{43}$. However, the tsar and the boyars decided to seek advice on the matter only from the merchants, and not a Sobor. The next day the merchants having business dealings with foreigners were indeed assembled, but they were not questioned at a meeting of a Sobor: they conversed only with the participants of Russian-English negotiations. The merchants came to the conclusion that the English should not be granted privileges, however, they concluded their statement quite traditionally, saying that they would approve any decision of the sovereign. Having learnt the opinion of the merchants, the Boyarskaya Duma decided to deny the English ambassador his request. Tsar Michael, in his turn, after listening to the report of the boyars, confirmed their decision ${ }^{44}$.

Summing up the examination of the history of the functioning of the Zemsky Sobor at the end of the $16^{\text {th }}$ - early $17^{\text {th }}$ century, we must state that a careful analysis of historical sources makes us agree with the opinion of L. V. Tcherepnin, who wrote that in the history of estate-representation in Russia of $16^{\text {th }}-17^{\text {th }}$ centuries there is «still much uncertainty» ${ }^{45}$. Even Zemsky Sobors of 1598 and 1613, which convening is not doubted by researchers, according to extant sources, were not assembled in composition to be perceived by people of the time as correct and authoritative. The documents of the beginning of the $17^{\text {th }}$ century allow us to conclude that in the minds of the people of the time a fully legitimate Zemsky Sobor was the one that was attended not only by the higher clergy and the members of the Tsar's court, but also by representatives of the provinces. At the Sobor of 1598, due to the swiftness of the election Boris Godunov as a tsar, the representatives of towns were absent (with the exception of the provincial nobility who happened to be in the capital on business). The Sobor of 1613 was planned to assemble the most complete representation of towns and districts, but the gathering of elected people in Moscow was dragging on, and, consequently, the issue of the election

43. TCherepnin, L. V.: Zemskie sobory, p. C. 226-227.

44. Posolskaya kniga po svyazyam Rossii s Angliey 1614-1617 gg. Moscow, 2006, pp. 150-155.

45. TCherePnin, L. V.: Zemskie sobory, p. C. 166. 
DMITRY VLADÍMIROVICH LISÉYTSEV

ZEMSKY SOBORS OF THE LATE 16TH - EARLY 17TH CENTURY IN RUSSIA:

HISTORIOGRAPHICAL STEREOTYPES IN THE REFLECTION OF HISTORICAL SOURCES

of the tsar was decided by the pressure of armed Cossacks on the members of the Sobor that had not yet gathered in full. Convening of the Sobors in 1604-1612 years raises serious doubts; likewise, there is insufficient evidence to confirm the thesis that during 1613-1619 the Sobors were active without dissolution for three consecutive years. Only at the beginning of 1616 a Zemsky Sobor was assembled in Moscow for approval of the decision about imposing an emergency tax (so-called «third fifth»). Not all estates were represented at this Sobor: according to extant charters, only the representatives of the merchant and artisan people and blackhundred peasantry were invited for the participation in it. The latter circumstance indicates that in the early $17^{\text {th }}$ century the Zemsky Sobor was perceived not so much a meeting of representatives of various estates, as a gathering of persons representing different lands of Muscovy: by the convocation of a Sobor the government wanted to achieve primarily the territorial but not estate representation ${ }^{46}$.

Thus, the view established in historical works that the beginning of the $17^{\text {th }}$ century was the heyday of a political institution of Zemsky Sobors is in need of revision or additional arguments.

\section{BIBLIOGRAPHY}

Akty, otnosyashchiesya $k$ istorii Zapadnoy Rossii, sobrannye i izdannye Arkheograficheskoy ekspeditsiey imperatorskoy Akademii nank, t. IV. Saint Petersburg, 1851.

Akty sluzhilykh zemlevladeltsev XV-nachala XVII v. Sbornik dokumentov, t. II. Moscow, 2001.

Akty, sobrannye v bibliotekakh i arkhivakh Rossiyskoy imperii Arkheograficheskoy ekspeditsiey imperatorskoy Akademii nank, t. II. Saint Petersburg, 1836.

Akty vremeni pravleniya Vasiliya Shuyskogo (19 maya 1606 - 17 iynlya 1610 g.). Moscow, 1914.

Avaliani, S. A.: Zemskie sobory. Literaturnaya istoria zemskikh soborov. Odessa, 1916.

Dopolneniya k Aktam istoricheskim, sobrannye i izdannye Arkheograficheskoy komissiey, t. I. Saint Petersburg, 1846.

Dvortsovye razryady, izdannye vtorym Otdeleniem sobstvennoy ego imperatorskogo velichestva kantselyarii, t. I. Saint Petersburg, 1850.

Klyuchevsky, V. O.: «Sostav predstavitelstva na Zemskikh soborakh Drevney Rusi (posvyashchaetsya B. N. Tchicherinu)», KLYUCHEvsky, V. O.: Sochineniya v devyati tomakh, t. VIII. Moscow, 1990, pp. 227-334.

KoRETSKY, V. I.: «Materialy po istorii Zemskogo sobora 1575 goda i postavlenii Simeona Bekbulatovicha «velikim knyazem vsea Rusii», Arkheografichesky ezhegodnik za 1969 god. Moscow, 1971, pp. 296-304.

46. Liseytsev, D. V.: «Legitimnost verkhovnoy vlasti v Rossii v epokhu Smuty: k voprosu o statuse "vybornykh ludey '”, Rossiyskaya istoriya, n’ 4, 2014, pp. 146-154. 
DMITRY VLADÍMIROVICH LISÉYTSEV

ZEMSKY SOBORS OF THE LATE 16TH - EARLY 17TH CENTURY IN RUSSIA:

HISTORIOGRAPHICAL STEREOTYPES IN THE REFLECTION OF HISTORICAL SOURCES

KoRETSKy, V. I.: «Zemsky sobor 1575 g. i chastichnoe vozrozhdenie oprichniny», Voprosy istorii, 5, 1967, pp. 32-50.

Koretsky, V.I., Lukichev, M. P., Stanislavsky, A. L.: «Dokumenty o natsionalno-osvoboditelnoy borbe v Rossii v 1612-1613 gg.», Lukichev, M. P.: Boyarskie knigi XVII veka: Trudy po istorii i istochnikovedeniyu. Moscow, 2004, pp. 198-234.

KorZInIN, A. L.: «Zemsky sobor 1566 g. v otechestvennoy istoriografii», Vestnik SPbGU, seriya 2, 3, 2011, pp. 11-23.

Latkin, V. N.: Zemskie sobory Drevney Rusi, ikh istoria i organizatsiya sravnitelno $s$ zapadnoevropeyskimi predstavitelnymi uchrezhdeniyami. Saint Petersburg, 1885.

LeontJev, A. K.: "Gosudarstvenny stroy», Ocherki russkoy kultury XVII veka, t. 1. Moscow, 1979, pp. 297-322.

Liseytsev, D. V.: «Demokratiya Smutnogo vremeni: kak prokhodil Zemsky Sobor 1613 goda», Rodina, 2, 2013, pp. 14-17.

LISEYTSEv, D. V.: «K datirovke sostavleniya tsarskikh utverzhdennykh gramot kontsa XvI - nachala XVII v.», Mininskie chteniya: Trudy uchastnikov mezhdunarodnoy nauchnoy konferentsii. Nizhegorodsky gosudarstvennyj universitet imeni N.I. Lobachevskogo (24-25 oktyabrya 2008 g.). Nizhny Novgorod, 2010, pp. 24-31.

Liseytsev, D. V.: «Legitimnost' verkhovnoy vlasti v Rossii v epokhu Smuty: k voprosu o statuse «vybornykh ludey»», Rossiyskaya istoriya, 4, 2014, pp. 146-154.

Liseytsev, D. V.: «Novoe izvestie o deyatel'nosti sobora v 1614 godu», Soslovnoe predstavitelstvo $v$ Rossii $v$ kontekste evropeyskoy istorii (vtoraya polovina XVI- seredina XVII vv.). Mezdunarodnaya nauchnaya konferentsiya. 7-10 oktyabrya 2013 g. Tezisy dokladov. Moscow, 2013, pp. 72-74.

Marzheret J. Sostoyanie Rossiyskoy imperii. J. Marzheret $v$ dokumentakh $i$ issledovaniyakh: (Teksty, kommentarii, stat'i). Moscow, 2007.

Morozov, B. N. y Stanislavsky, A. L. (eds.): «Povest' o Zemskom sobore 1613 goda», Voprosy istorii, 5, 1985, pp. 89-96.

Narodnoe dvizhenie v Rossii v epokhu Smuty nachala XVII veka, 1601 - 1608 gg.: Sbornik dokumentov. Moscow, 2003.

«Novye akty Smutnogo vremeni. Akty podmoskovnykh opolcheniy i Zemskogo sobora 1611-1613 gg.», Chteniya v Imperatorskom obschestve istorii i drevnostey rossiyskikh pri Moskovskom universitete, 1911, vol. 4.

Platonov, S. F.: «Moskovskie Zemskie sobory Xvi i XviI vekov», Platonov, S. F.: Sobranie sochineniy v shesti tomakh, vol. 1. Moscow, 2010, pp. 23-184.

Platonov, S. F.: «Zametki po istorii moskovskikh Zemskikh soborov», Platonov, S. F.: Sobranie sochineniy v shesti tomakh, vol. 3. Moscow, 2012, pp. 7-25.

Podvig Nizhegorodskogo opolcheniya, vol. 2. Nizhny Novgorod, 2011.

Polnoe sobranie russkikh letopisey, vol. 34. Moscow, 1978.

Posolskaya kniga po svyazyam Rossii s Angliey 1614-1617 gg. Moscow, 2006.

Sbornik Novgorodskogo obshchestva lubiteley drevnosti, vol. V. Novgorod, 1911.

Sobranie gosudarstvennykh gramot $i$ dogovorov, khranyashchikhsya v Gosudarstvennoy kollegii inostrannykh del, t. II. Moscow, 1819, t. III. Moscow, 1822. 
Sukhotin, L. M.: Pervye mesyatsy tsarstvovaniya Mikhaila Fedorovicha. (Stolptsy Pechatnogo prikaza). Moscow, 1915.

Tcherepnin, L. V.: Zemskie sobory Russkogo gosudarstva v XVI-XVII vv. Moscow, 1978.

Tikнomirov, M. N.: «Soslovno-predstavitelnye uchrezhdeniya (Zemskie sobory) v Rossii Xvi veka», Tikнomiro7uuuv, M. N.: Rossiyskoe gosudarstvo XV-XVII vekov. Moscow, 1973, pp. 42-69.

Veselovsky, S. B.: Sem'sborov zaprosnykh ip'atinnykh deneg v pervye gody tsarstvovaniya Mikhaila Fedorovicha. Moscow, 1908.

Vosковочniкоva, N. P.: «K istorii finansovoy politiki russkogo gosudarstva v nachale XVII v.», Istoriya SSSR, 3, 1986, pp. 156-161.

Zabelin, I. E.: Minin i Pozharsky. «Pryamye» $i$ «krivye» v Smutnoe vremja. Saint Petersburg, 2005.

Zamyatin, G. A.: «Iz istorii borby Shvetsii i Polshi za moskovsky prestol v nachale XVII veka. Padenie kandidatury Karla Filippa i votsarenie Mikhaila Fedorovicha», Zamyatin, G. A.: Rossiya i Shvetsiya v nachale XvII veka. Ocherki politicheskoy $i$ voennoy istorii. Saint Petersburg, 2008, pp. 31-242.

Zimin, A. A.: «Akty Zemskogo sobora 1612-1613 gg.», Zapiski otdela rukopisey Gosudarstvennoy ordena Lenina biblioteki SSSR imeni V.I. Lenina, t. 19. Moscow, 1957, pp. 186-194. 
